\title{
Research Report on Quality of Life of the Scattered Ethnic Minorities under the Background of Targeted Poverty Alleviation in Hainan Province*
}

\author{
Gongtao Cai \\ Hainan University \\ Haikou, China
}

\author{
Yanqing $\mathrm{Xu}$ \\ Hainan University \\ Haikou, China
}

\begin{abstract}
In Hainan Province, there are nearly 1/10 scattered minority groups in the total population. The scattered minority groups in our province are mainly distributed in backward and remote areas, and the overall quality of life is poor. Therefore, we should know the quality of life of the scattered minorities in Hainan Province under the background of targeted poverty alleviation, explore the major factor affecting the quality of life, and formulate relevant policies to improve the quality of life of the scattered minorities in our province and protect the rights and interests of the scattered minorities. According to the brief form of quality of life of WHO (WHOQOL-BREF), the paper carried out investigation and questionnaire from four aspects, including the physical and psychological fields, social relations and environment. The Statistic Package for Social Science (SPSS) is used to analyze the four fields in quality of life and correlation with income factors. According to the survey, 232 scattered ethnic minorities were randomly selected. Among them, 136 people were living in poverty. The proportion of the poor population in the total survey population is $\mathbf{5 8 . 8 7 \%}$. Income is the main factor affecting the quality of life of the scattered minorities in our province. The scores of them in the four fields respectively are $60.76+10.88$ (physiological field), 67.24 + 13.55 (psychological field), 70.50 + 14.02 (social relations) and $68.7+14.91$ (environment), which are relative low.
\end{abstract}

Keywords-scattered ethnic minorities; targeted poverty alleviation; quality of life; factors; correlation analysis

\section{INTRODUCTION}

"Targeted poverty alleviation" is as opposed to "extensive poverty alleviation". The concept of targeted poverty alleviation was formally proposed by Chairman $\mathrm{Xi}$ when he visited Western Hunan in November 2013. The connotation of targeted poverty alleviation lies in "targeting", including accurate identification, helping poor households and managing funds for poverty alleviation precisely, establishing and improving the system of poverty alleviation, and clearing poverty alleviation goals. Through refining and quantifying the indicators and concretizing job responsibilities and other ways, promote targeted poverty alleviation work, and achieve the

*This paper is Supported by Hainan Provincial Natural Science Foundation of China "Research on Influencing Factors and Action Mechanism of Hainan's Targeted Poverty Alleviation Policy in the Effective Implementation" (718QN223). goal of poverty alleviation, reduce the poor population in China, and realize common rich. The economic backwardness leads poor conditions of local residents in education, medical treatment and housing, and the per capita income level is low. The overall quality of life will decrease because of poverty.

There are 9171300 permanent residents in Hainan. The majority are Han people. There are totally 38 minorities, including Li, Miao, Hui and other minority groups. There is a population of 1476100 minorities, accounting for $16.67 \%$ of the total population in Hainan. Among them, there are $1319100 \mathrm{Li}$ people, 68400 Miao people, 10700 Hui people and 77900 other minorities. Ethnic minorities in Hainan mainly are living together in a small area. In Hainan, only six ethnic autonomous counties are totally composed by two ethnic groups, including Li and Miao people. So, there are many scattered ethnic minority groups in Hainan. Scattered ethnic minorities generally refer to sporadic-distributed minorities without regional autonomy. There are 678000 scattered ethnic minorities, accounting for $45.93 \%$ of the total ethnic minority population. The per capita GDP of permanent residents is 40983.75 Yuan. The per capita GDP of people in Sanya, Haikou and Chengmai surpasses 50000 Yuan, ranking the top three in Hainan. At the bottom of ranks are per capita GDPs of Qiongzhong $\mathrm{Li}$ and Miao Autonomous County, Ledong Li Autonomous County and Wuzhishan City. The per capita income of these places is less than 1/2 of Haikou and Sanya. Moreover, the economies of minority autonomous areas are generally backward, and the regional economic development is not balanced. In the minority areas, such as Wuzhishan City, the economy is backward, so the quality of life of the scattered minorities is not high.

The targeted poverty alleviation policies of all cities and counties of Hainan are formulated and developed mainly according to 2016-2017 Targeted Poverty Plan and Policy Interpretation in Hainan Province. The specific measures to carry out the targeted poverty alleviation in Hainan cities and counties are as follows: 1. Identify the poor households by entering villages and households. Strictly implement the poor household identification procedures of "two publicities and one announcement" and clear households not meeting the standards of poor households timely. 2. Improve the infrastructure construction and ram the foundation of poverty alleviation. Strengthen the construction of the infrastructure in 
towns and old areas, and realize the foreign transport capacity in products. 3. Innovate the mode of poverty alleviation and integrate various measures of poverty alleviation. Integrate "three-party" blood-making poverty alleviation, "fivenetwork" blood-transfusion poverty alleviation and "tensubsidy" detail-revealing poverty alleviation to realize poverty-shaking-off of poor population quickly. 4. Use ecommerce to alleviate poverty. Use the practical mode of internet + agriculture and e-commerce + poverty alleviation. Build online and offline transaction platforms for poor households to sell high-quality agricultural products, which can help improve effect of industrial poverty alleviation and targeted support. 5. Help targeted poverty alleviation with finance. Use funds and materials to achieve double guarantee. As for poor people because of lacking resources, the government shall give financial support to buy the corresponding materials for the impoverished population to achieve industrial development. As for poor people because of lacking entrepreneurial funds, the governments shall cooperate with financial organizations to provide loan guarantees for these people.

Under the background of targeted poverty alleviation, it helps quantify and refine rights of scattered ethnic groups on the micro level, and understand quality of life and causes of poor scattered minorities through subjective evaluation of these people in medical care, education and housing and other aspects. At the same time, from the perspective of targeted poverty alleviation in Hainan, it puts forward some countermeasures and suggestions to effectively improve the quality of life of scattered minorities, and makes full use of the current provincial government's policies and resources to promote the development of "poverty alleviation" in Hainan's scattered minorities.

\section{RESEARCH METHODS}

\section{A. The Selection of Research Methods}

This paper first uses method of literature. Through China HowNet, network resources and collection books of school library, the related literature materials are obtained. Then through the government website the public data of this topic are obtained and analyzed to provide certain theories and data support for the research of this paper.

Secondly, use the empirical research method. The author uses WHOQOL-BREF in Chinese and designs questionnaire, selects scattered minorities of three counties as respondents and finds problems and puts forward countermeasures through specific cases.

Then take the method of case interview: mainly selected the minority ethnic groups in three cities and counties. Obtain information of these groups in satisfactory and recognition in their present quality of life, and let them describe what kinds of support they need from the government. Let them give suggestions and countermeasures on their targeted poverty alleviation policy in their living areas. Communicate with the relevant persons in charge of the national bureau of religious affairs and the Poverty Alleviation Office in the tree cities and counties, and know poverty alleviation measures local governments take for scattered ethnic monitories, thus sort suggestions and opinions from the government, scholars and the mass to improve quality of life of scattered ethnic minorities.

Pay attention to the factor analysis by questionnaire method, consider all aspects of quality of life of scattered minorities, realize the quantitative analysis by using SPSS and analyze main factors affecting the quality of life of ethnic minorities in various fields. Through the correlation analysis, 17 indicators affecting quality of life of scattered minorities are obtained, and it helps determine which one is the determinative factor. Considering the cultural literacy of the minority people in Hainan Province, the author adopts the familiar terms in the design of the questionnaire.

\section{B. The Theoretical Basis of the Design of Indicators in Questionnaire}

The design of the questionnaire is based on the brief form of the quality of life of WHO (WHOQOL-BREF). The author set four first-level indicators and 17 secondary indicators according to the form of quality of life.

TABLE I. INDICATOR SYSTEM IN QUESTIONNAIRE

\begin{tabular}{|c|c|}
\hline First-Level Indicators & Secondary Indicators \\
\hline Physiological field & $\begin{array}{l}\text { 1. energy and tiredness } \\
\text { 2. sleep and rest }\end{array}$ \\
\hline Psychological field & $\begin{array}{l}\text { 3. positive feelings } \\
\text { 4. thought, learning, memory, and attention } \\
\text { 5. self-esteem } \\
\text { 6. figure and appearance } \\
\text { 7. negative feelings }\end{array}$ \\
\hline Social relations & $\begin{array}{l}\text { 8. personal relationships } \\
\text { 9. The degree of satisfaction about required social } \\
\text { support }\end{array}$ \\
\hline Environment & $\begin{array}{l}\text { 10. social security guarantee } \\
\text { 11. housing environment } \\
\text { 12. economic sources } \\
\text { 13. medical service and social security } \\
\text { 14. opportunities to access to new information and } \\
\text { skills } \\
\text { 15. opportunities to access to leisure and } \\
\text { entertainment } \\
\text { 16. environmental conditions (pollution / climate) } \\
\text { 17. traffic conditions }\end{array}$ \\
\hline
\end{tabular}

III. ANALYSIS OF THE PRESENT SitUATION OF THE QUALITY OF LIFE OF THE SCATTERED ETHNIC MINORITIES

\section{A. The Overall Quality of Life of Scattered Minority Groups in the Three Cities and Counties}

The survey and interview were conducted in Haikou, Lingshui Li Autonomous County and Wuzhishan City. In the survey there are 232 scattered minorities in 9 regions of the three cities and counties. Among them there are 136 poor households, accounting for $58.87 \%$ of the total investigated population. 
TABLE II. SCORES ON THE QUALITY OF LIFE OF ETHNIC MiNORITY GROUPS IN THREE CITIES AND COUNTIES

\begin{tabular}{|l|l|l|l|l|l|}
\hline & \multicolumn{1}{|c|}{$\mathbf{N}$} & Min. & Max. & Mean & \multicolumn{1}{|c|}{$\begin{array}{l}\text { Standard } \\
\text { Deviation }\end{array}$} \\
\hline Life field & 232 & 2 & 10 & 6.76 & 1.878 \\
Psychological & 232 & 6 & 24 & 16.81 & 3.388 \\
field & 232 & 3 & 10 & 7.50 & 1.402 \\
Social relations & 232 & 14 & 40 & 27.48 & 5.962 \\
$\begin{array}{l}\text { Environment } \\
\text { Effective N (list } \\
\text { state) }\end{array}$ & 232 & & & & \\
\hline
\end{tabular}

"Table II" shows 232 minority residents were randomly selected. The results showed the average scores of quality of life of residents in physiological field $(60.76+10.88)$, psychology $(67.24+13.55)$ points, social relations $(70.50+$ $14.02)$, and environment $(68.70+14.91)$. (mean \pm standard deviation)

In the 232 respondents, there were 165 people with a monthly income of less than 3000 Yuan, accounting for $71.1 \%$, and 48 with a monthly income of $3000 \sim 5000$ Yuan, accounting for $20.7 \%$. The overall income distribution of scattered ethnic groups is skewed. Most of their monthly income is less than 3000 Yuan or between 3000 Yuan and 5000 Yuan. The average monthly income of Hainan is 5106 Yuan, which indicates that the income of scattered minorities is generally low.

Among the 232 respondents, 164 were sick (including fever, colds and other chronic diseases), accounting for $70.7 \%$, and 68 were not sick at that time, accounting for $29.3 \%$. They were not all serious ill, but sick will affect the satisfaction of life of the scattered minority people. At same time, the physical pain will bring economic burden. So, one of the causes of poverty is sickness for majority poor people.

\section{B. Analysis of the Current Factors of the Quality of Life of the Scattered Minorities in Three Cities and Counties}

1) Analysis of current factors in physiological fields

In the survey it mainly involves two aspects of scattered ethnic minorities in physiological field. One is about satisfaction of minority about their sleep. The other is whether there is energy for them to deal with daily life. The author also carried correlation analysis of income and physical quality.

It is known from "Table IV" that p, equaling to 0.000 is less than 0.01 . So, the monthly income is significantly related to the quality of life in the physiological field. And can be seen from "Table III", 165 people's monthly income is less than 3000 Yuan. The scores of these people are concentrated between 6 and 8 in physiological field. Among them, the number of people with score less than 8 is 165 , accounting for $71.52 \%$. 48 people's monthly income is between 3000 and 5000. Among, them, the number of people with score less than 8 is 25 , accounting for $52.08 \%$. 10 people's monthly income is between 5000 and 8000, and all of them scored 9. 6 people's monthly income is between 8000 and 10000. Only one scored 9 and five people scored 10. Three people's monthly income was above 10000 Yuan, and their scores were 10. As a result, with the increase of monthly income, the score of the quality of life in the physiological field is also higher, and it is positive correlation.

TABLE III. MONTHLy InCOME * CROSS TABUlation IN THE PHYSIOLOGY

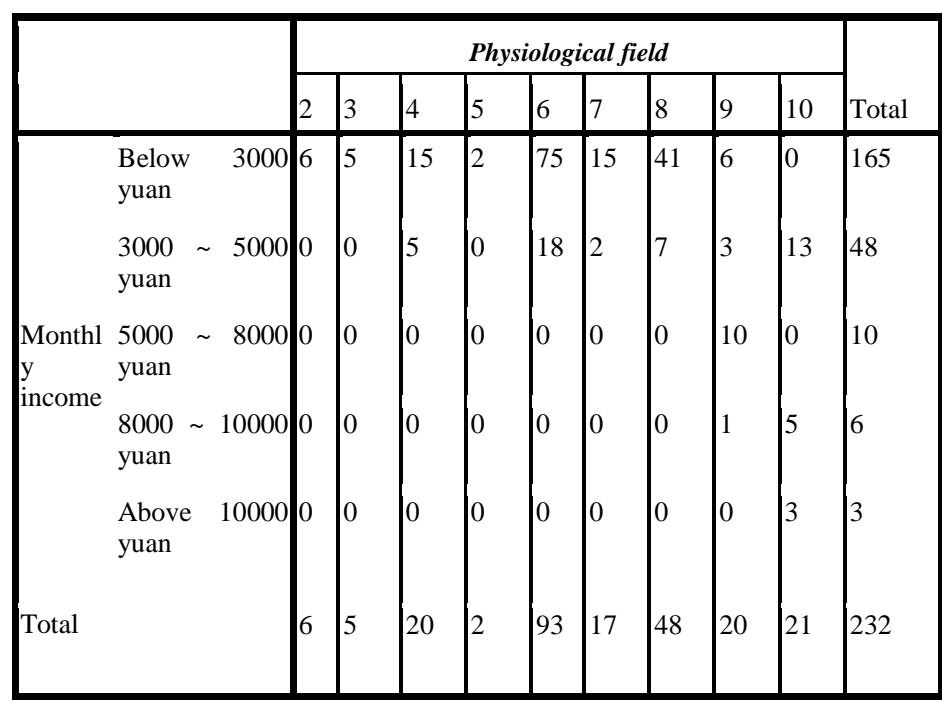

TABLE IV. CORRELATION

\begin{tabular}{|c|c|c|c|}
\hline & & Physiology & Your Monthly Income \\
\hline Life field & $\begin{array}{l}\text { Pearson correlation } \\
\text { Significance (bilateral) } \\
\mathrm{N}\end{array}$ & $\begin{array}{c}1 \\
232 \\
\end{array}$ & $\begin{array}{c}.488 * * \\
.000 \\
232\end{array}$ \\
\hline $\begin{array}{l}\text { Monthly } \\
\text { income }\end{array}$ & $\begin{array}{l}\text { Pearson correlation } \\
\text { Significance (bilateral) } \\
\mathrm{N}\end{array}$ & $\begin{array}{c}.488 * * \\
.000 \\
\mathrm{~N}\end{array}$ & $\begin{array}{c}1 \\
232\end{array}$ \\
\hline
\end{tabular}

**. Significant correlation at the level of .01 (bilateral)

TABLE V. CHI-SQuARE TEST

\begin{tabular}{|c|c|c|c|}
\hline & Value & df & $\begin{array}{l}\text { Progressive Sig. } \\
\text { (bilateral) }\end{array}$ \\
\hline Pearson chi-square & $224.654 a$ & 32 & .000 \\
\hline Likelihood ratio & 146.289 & 32 & .000 \\
\hline $\begin{array}{l}\text { Linear and linear } \\
\text { combination }\end{array}$ & 54.933 & 1 & .000 \\
\hline $\mathrm{N}$ in valid cases & 232 & & \\
\hline
\end{tabular}

${ }^{\mathrm{b} .}$ The expected count of cell 37 (82.2\%) is less than 5 . The minimum expectation count is .03

2) Analysis of Current Factors in Psychological Field

The investigation of psychological field mainly involves in three aspects, including happiness of scattered ethnic minorities, job satisfaction, and social status and self-esteem of scattered ethnic minorities. Income is closely related to psychology. This factor plays a decisive role in the quality of psychology. The author has carried correlation analysis of income and quality of psychology. 
TABLE VI. Monthly InCOME * Cross TABulation In The PSYCHOLOGY

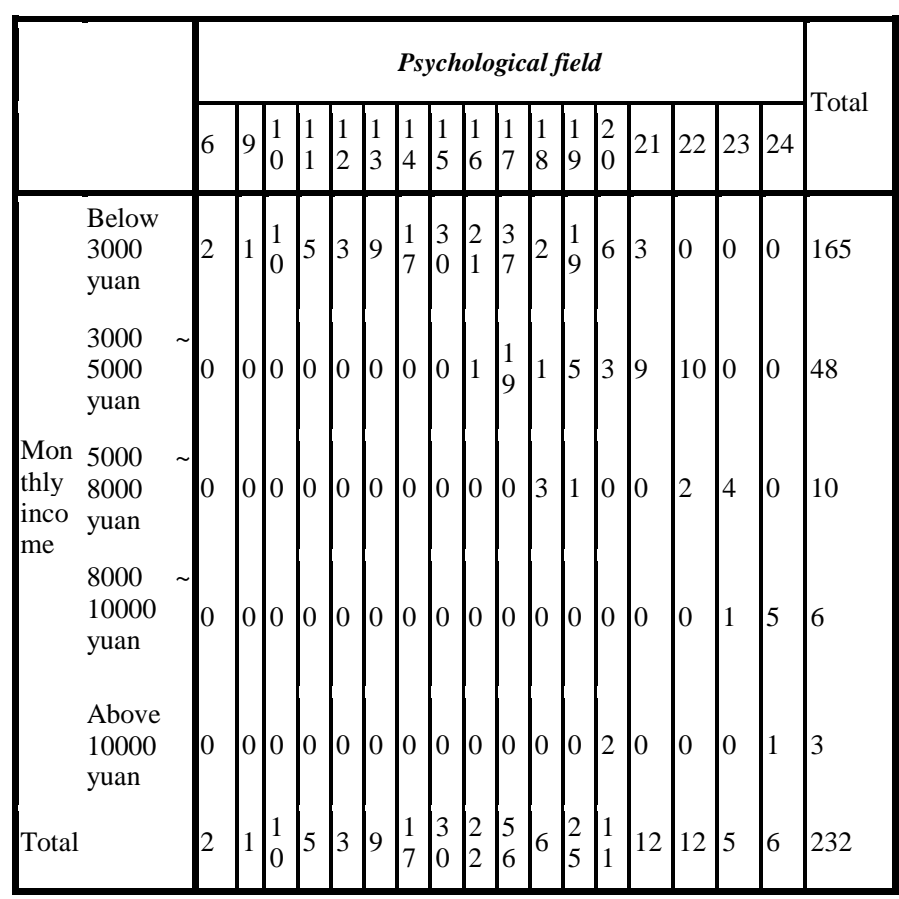

TABLE VII. CORRELATION

\begin{tabular}{|c|c|c|c|}
\hline & & $\begin{array}{l}\text { Your Monthly } \\
\text { Income }\end{array}$ & $\begin{array}{c}\text { Psychologic } \\
\text { al Field }\end{array}$ \\
\hline Monthly income & $\begin{array}{l}\text { Pearson correlation } \\
\text { Significance } \\
\text { (bilateral) } \\
\mathrm{N}\end{array}$ & 232 & $\begin{array}{l}.601 * * \\
.000 \\
232\end{array}$ \\
\hline Physiological field & $\begin{array}{l}\text { Pearson correlation } \\
\text { Significance } \\
\text { (bilateral) } \\
\text { N }\end{array}$ & $\begin{array}{ll} & .601^{* * *} \\
.000 & \\
232 & \end{array}$ & 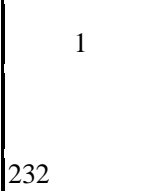 \\
\hline
\end{tabular}

**. Significant correlation at the level of .01 (bilateral)

TABLE VIII. CHI-SQUARE TEST

\begin{tabular}{|l|l|l|l|}
\hline \multicolumn{1}{|c|}{ Value } & \multicolumn{1}{|c|}{ df } & $\begin{array}{l}\text { Progressive Sig. } \\
\text { (bilateral) }\end{array}$ & \multicolumn{1}{c|}{ Value } \\
\hline $\begin{array}{l}\text { Pearson chi-square } \\
\text { Likelihood ratio } \\
\text { Linear and linear } \\
\text { combination } \\
\text { N in valid cases }\end{array}$ & $807.152 \mathrm{a}$ & 64 & .000 \\
214.959 & 64 & 1 & .000 \\
\hline
\end{tabular}

It is known from "Table VII" that p, equaling to 0.000 is less than 0.01 . So, the monthly income is significantly related to the quality of life in the psychological field. And can be seen from "Table VI", 165 people's monthly income is less than 3000 yuan. The scores of these people are concentrated between 14 and 17 in psychological field. Among them, the number of people with score less than 20 is 156 , accounting for $94.55 \%$. 48 people's monthly income is between 3000 and 5000. Among them, the number of people with score less than 20 is 26 , accounting for $54.17 \%$. 10 people's monthly income is between 5000 and 8000 . Among them, the number of people with score less than 20 is 4 , accounting for $40 \%$. 6 people's monthly income is between 8000 and 10000 . Only one scored 23 and five people scored 24. Three people's monthly income was above 10000 yuan, and one scored 24 and the other two scored 20. As a result, with the increase of monthly income, the score of the quality of life in the psychological field is also higher.

3) Analysis of the current factors in social relations

The author mainly carried out investigation on third-level emotion and belonging need according to Maslow's hierarchy of needs theory in social relations of scatted ethnic minorities. It mainly interviewed their satisfaction about their personal relationship and support from friends. The author carried out correlation analysis of their income and social relations.

TABLE IX. MONTHLY INCOME * CROSS TABULATION IN SOCIAL RELATIONS

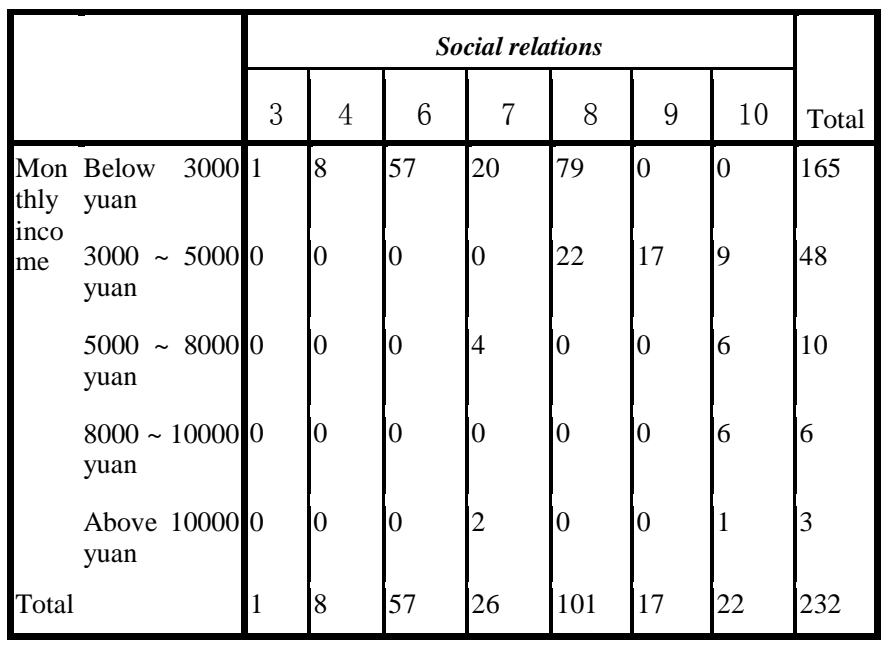

TABLE X. CORRELATION

\begin{tabular}{|ll|l|l|}
\hline & \multicolumn{1}{|c|}{$\begin{array}{c}\text { Your Monthly } \\
\text { Income }\end{array}$} & Social Relations \\
\hline $\begin{array}{l}\text { Monthly } \\
\text { income }\end{array}$ & $\begin{array}{l}\text { Pearson correlation } \\
\text { Significance } \\
\text { (bilateral) }\end{array}$ & 1 & $.524 * *$ \\
& $\mathrm{~N}$ & .000 \\
\hline $\begin{array}{l}\text { Social } \\
\text { relations }\end{array}$ & $\begin{array}{l}\text { Pearson correlation } \\
\text { Significance } \\
\text { (bilateral) }\end{array}$ & $.524 * *$ & 232 \\
& $\mathrm{~N}$ & .000 & 1 \\
\hline
\end{tabular}

**. Significant correlation at the level of .01 (bilateral) 
TABLE XI. CHI-SQUARE TEST

\begin{tabular}{|l|l|l|l|}
\hline & \multicolumn{1}{|c|}{ Value } & \multicolumn{1}{c|}{ df } & \multicolumn{1}{c|}{ Progressive Sig. (bilateral) } \\
\hline Pearson chi-square & $223.365 \mathrm{a}$ & 24 & .000 \\
Likelihood ratio & 201.486 & 24 & .000 \\
Linear and linear combination & 63.329 & 1 & .000 \\
$\mathrm{~N}$ in valid cases & 232 & & \\
\hline
\end{tabular}

It is known from "Table $X$ " that $p$, equaling to 0.000 is less than 0.01 . So, the monthly income is significantly related to the quality of life in the social relations. And can be seen from "Table IX", 165 people's monthly income is less than 3000 yuan. The scores of these people are concentrated between 6 and 8 in social relations. Among them, the number of people with score less than 8 is 86 , accounting for $52.12 \%$. 48 people's monthly income is between 3000 and 5000. Among them, nobody's score was less than 8 , accounting for $0 \% .10$ people's monthly income is between 5000 and 8000. Among them, the number of people with score less than 8 is 4 , accounting for $50 \%$. The rest four's scores are all 10.6 people's monthly income is between 8000 and 10000 . Their scores are all 10 points. Three people's monthly income was above 10000 yuan, and one scored 10 and the other two scored 7. As a result, with the increase of monthly income, the overall quality of life in the psychological field can also be improved. d. The expected count of cell 26 (74.3\%) is less than 5. The minimum expectation count is 01

4) Analysis of the current factors in environment

In the environment of scattered ethnic minorities, the author designed 9 questions in the questionnaire. 1. Are you feel well about your daily life? 2. Are you satisfied about your housing condition? 3 . Is there enough money for you to live life? 4. Is it convenient to go to nearby clinic? 5. Do you know the government's poverty alleviation measures in your life? 6 . Do you have time to take leisure activities (such as, playing mahjong etc.) 7. Is your living environment good for health? 8. How do you go outside? 9 Are you satisfied about the government's poverty alleviation measures? According to Maslow's hierarchy of needs theory, the author designed questionnaire and carried out investigation from six aspects of scatted ethnic minorities, including clothing, foods, housing, travel type, medical care and understanding of policies. It helps fully understand the basic material guarantee, safety status, satisfaction about other's esteem on them. The author carried correlation analysis of their monthly income and environment.

TABLE XII. MONTHLY INCOME * CROSS TABULATION IN ENVIRONMENT

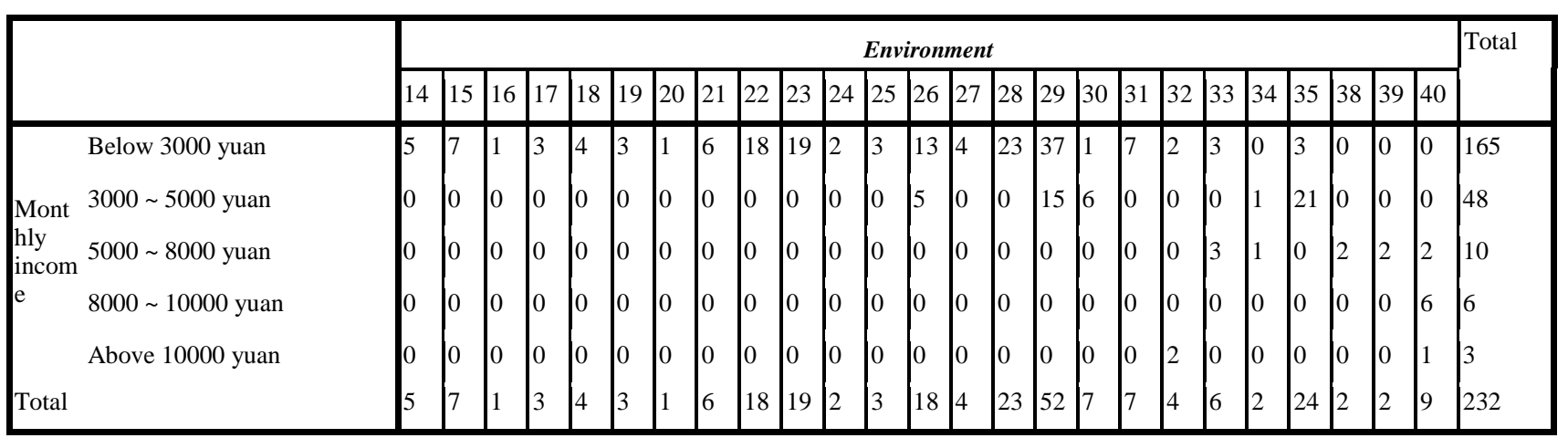

It is known from "Table XIII" that p, equaling to 0.000 is less than 0.01 . So, the monthly income is significantly related to the quality of life in the environment. And can be seen from "Table XII", 165 people's monthly income is less than 3000 yuan. The scores of these people are concentrated between 22 and 29 in environment. Among them, the number of people with score less than 32 is 157 , accounting for $95.15 \% .48$ people's monthly income is between 3000 and 5000. Among them, the number of people less than 32 points is 21 , accounting for $56.25 \%$. 10 people's monthly income is between 5000 and 8000 . Among them, the number of people with score less than 32 is zero, accounting for $0 \%$. 6 people's monthly income is between 8000 and 10000 . They all get full scores. Three people's monthly income was above 10000 yuan, and one get full scores and the other two get 32. As a result, the higher monthly income, the higher the scores of overall quality of life in the environment.

\section{CONCLUSION}

The author has carried correlation analyses of their income with their physiology, psychology, social relations and environment. The author found income is the main factor affecting quality of life of scattered ethnic minorities. With the increase of income, the overall quality of life of scattered ethnic minorities also will be improved. Therefore, local government shall stress to make measures to improve the income of scattered ethnic minorities in the implementation of targeted poverty alleviation policy. 
TABLE XIII. CORRELATION

\begin{tabular}{|ll|l|l|}
\hline & \multicolumn{1}{|c|}{ Environment } & \multicolumn{1}{c|}{ Your Monthly Income } \\
\hline Environment & Pearson correlation & & $.625^{* *}$ \\
& Significance (bilateral) & 232 & .000 \\
& $\mathrm{~N}$ & 232 \\
\hline Monthly income & Pearson correlation & $625^{* *}$ & 1 \\
& Significance (bilateral) & .000 & 232 \\
& $\mathrm{~N}$ & 232 & \\
\hline
\end{tabular}

**. Significant correlation at the level of .01 (bilateral)

TABLE XIV. CHI-SQUARE TEST

\begin{tabular}{|l|l|l|l|}
\hline & \multicolumn{1}{|c|}{ Value } & \multicolumn{1}{|c|}{ df } & \multicolumn{1}{c|}{ Progressive Sig. (bilateral) } \\
\hline Pearson chi-square & $505.321 \mathrm{a}$ & 96 & .000 \\
Likelihood ratio & 257.056 & 96 & .000 \\
Linear and linear combination & 90.325 & 1 & .000 \\
$\mathrm{~N}$ in valid cases & 232 & & \\
\hline
\end{tabular}

The expected count of cell $117(93.6 \%)$ is less than 5 . The minimum expectation count is .01

Products, talent and capital

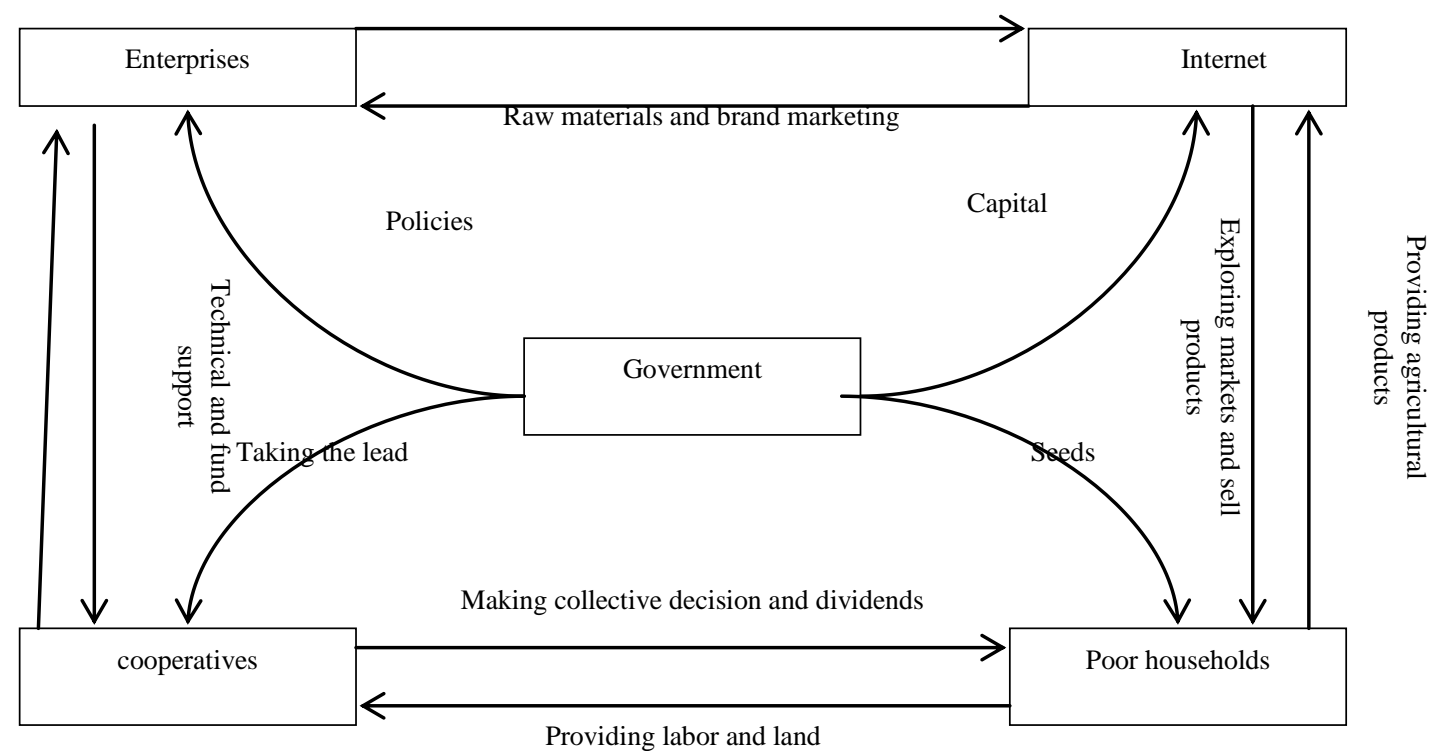

Fig. 1. "Enterprise + cooperatives + poor households + Internet" marketing mode.

The government should adopt various measures to carry out the policy of targeted poverty alleviation in order to improve the income of the scattered minorities in Hainan Province. Firstly, help change the ideological laziness of the scattered ethnic minorities. Their ideological laziness lies in three aspects: first, Hainan is located in the tropics, and has abundant natural resources. So, the local minorities are overwhelmingly dependent on natural resources. The foreign population seldom fights for the local resources. Second, the central region of Hainan is developed less, and local minorities exchange and contact with outside world less. People's thoughts are still relatively conservative, especially the traditional thought of being satisfied to live in their native land and unwilling to go outside for work and increase their income. 
Third, the targeted poverty alleviation policy Hainan government mainly takes is the financial-blood transfusion mode. As a result, local minorities are increasingly dependent on government subsidies, and have no motivation to rely on their own efforts. The ideological laziness results in the low quality of life of scattered ethnic groups in Wuzhishan and other central regions. So, local government first shall improve the development degree, especially in Wuzhishan. The government can invite foreigners to invest, start business and work in these areas. Thus, seize some resources by using of the method of attracting foreign population and arouse urgency of local scattered minorities. Secondly, adjust the poverty alleviation mode, and increase the acceptance costs of local scattered ethnic minorities in poverty alleviation. For example, examine the poverty-shaking-off of scattered ethnic minorities. The resources they accept shall be positively related to the final poverty-shaking-off result, and thus change their overdependence on financial funds.

Secondly, adjust the poverty alleviation mode. First, replace the financial-blood transfusion mode into the bloodmaking mode. Increase technical training and education by using relief funds, or centralize the use of relief resources and let specially-assigned person to use them to realize the reproduction of capital, such as, the development of cooperatives. Second, help farmers plant plants or raise animals, and at the same time, the government shall help them match with the production and marketing channels, provide timely market information and improve the corresponding infrastructure, which can help people to realize the production cycle and get rid of poverty. In addition, sound "difference" system to avoid system vacancy. If don't consider the causes of poverty of scattered groups and take uniform measures, it will waste relief resources or is not conducive to fully mobilize the enthusiasm and initiative of the people. As for design of system, not simply consider differences of minorities and Han people, but also examine whether the design of system will lead to artificial unfairness. For example, are there biases in urban and rural social security system? Are there discriminations in fiscal allocation? Is the design of system according to the urban-rural dual structure? In design of system, the government can invite the third party and relevant experts and scholars to participate in order to protect the interests of all parties within the scope. Finally, develop the development mode of "enterprise + cooperative + Internet + poor households", as shown in Figure 1. It is very import to fully excavate local characteristic resources. For instance, develop the production of tea in Wuzhishan City.

As shown above, in this mode, the government, as the core leading role, shall provide necessary policy support for enterprises to participate in, including policies on tax relief and to support enterprises. The government shall provide financial support for the construction of the online stores, and form the pattern of one village, one service station and one village, one online store in the rural areas. The government shall play a leading role in building cooperatives. The local township government shall be active in construction of cooperative and help poor households contact enterprises. As for poor households, the government shall provide seeds to plant plants or raise animals. In this mode, enterprises shall make full use of market. Enterprise can directly purchase raw materials from cooperatives and provide technical support, provide talent and financial support to online service stations of villages and sell products by the platform of internet. The cooperative, as bridge of enterprise and poor household, can provide raw materials for enterprises, and help enterprises contact, coordinate and manage farmers. At same time, cooperatives can bring more profits and dividends to farmers. Poor household, as the smallest unit of cooperative, can provide labor, land and raw materials to cooperatives, and can directly sell products on online store. The internet enterprises can explores markets for the product sell of farmers, and establish self brand by internet. In a word, this mode can connect products of farmers with market conveniently and quickly, help build characteristic enterprises for local minorities and form brand effect, and thus benefit the scattered minority households. Finally, improve the overall quality of life of scattered ethnic minorities.

\section{REFERENCES}

[1] Liu Shenglin, Wang Yulin, Zhuang Tianhui. Review of Targeted Poverty Alleviation based on the Method of Literature Research. Jiangxi Journal of Agricultural Sciences, 2015. V. 27 (12): 132-136.

[2] Ao Junde. Concept of Scattered Ethnic Minorities. Studies of Ethnics. 1992 (5): 8-16.

[3] Lu Pinghui. Analysis of the Concept of Scattered Ethnic Minorities. Journal of Northwest University for Nationalities: Philosophy Social Science Edition. 2011 (5): 45-50.

[4] Pei Ying. Concept of Scattered Ethnic Minorities and Relevant National Legal System Problems - Questions on the Concept of Scattered Ethnic Minorities. Studies of Ethnics. 1992 (5): 8-16.

[5] Fang Jiqian, Wan Chonghua and Shi Mingli. Research on Quality of Life and Measurement Form. Modern Rehabilitation. 2000, 4 (8): 1123 1126, and 1133 .

[6] Liao Qiuling, Wang Kangning, Yang Jing, Jing Yun and Chen Qiuyu. Analysis on the Status and Influencing Factors of the Quality of Life of the Residents in the Minority Areas of Southwest Hunan, Modern Preventive Medicine. 2015, 42 (8): 1452-1455.

[7] Zhang Gaohua, Liao Qiuling, Chen Manyang, Liu Xin and Chen Mingyang. Correlation between the Quality of Life and Family Function and Depression of the Left-behind Residents in the Minority Areas of North Guangdong. Preventive Medicine Forum. 2016 (4): 243-246.

[8] Dai Ying. Construction and Application of the Indicator System for the Performance Assessment of Targeted Poverty Alleviation Work. Labor Security World, 2017 (14).

[9] $\mathrm{Hu}$ Shanping. Construction of Performance Evaluation Index System for Targeted Poverty Alleviation. Journal of Shenyang Agricultural University, Sept. 2016, 18 (5): 513-520

[10] Chen Canping. Mechanism Research of Targeted Poverty Alleviation in Concentrated Poverty-stricken Areas - taking the poverty-stricken ethnic minority areas in Sichuan as example. Journal of Southwest University for Nationalities: Humanities and Social Sciences Edition, 2016 (4). 